Cite: Taks, M., \& Misener, L. (2016). Selecting sport events to serve public policy agendas. Case Studies in Sport Management (Special Issue on Statistics in Sport Management), 5(1), 98-108. DOI: $10.1123 /$ cssm.2015-0062.

Title: Selecting Sport Events to Serve Public Policy Agendas

\begin{abstract}
In this case, a local Sport Tourism Officer has been asked to prepare a recommendation for Evex City Council regarding which type(s) of event(s) the city should bid for, based on their public policy agenda of enhancing tourism for economic development purposes, and stimulating sport participation for residents. A questionnaire, a codebook, and a data set from two events, an international figure skating event and a provincial gymnastics event, are provided to assist in making a decision. The data set includes the spectators' identification with and motives for attending the events, tourism activities they participated in, as well as some socio-demographic variables. Analyses of the data and interpretation of the results should assist the sport tourism officer in providing accurate recommendations to policy makers. Theories and frameworks that underpin this case include: public policy schemas; identity, motives and tourism behavior of event attendees; sport participation outcomes from sport events; leveraging; and event portfolios.

Keywords: Attendees; Events; Motivation; Sport participation; Sport tourism; Statistics
\end{abstract}




\section{Case Problem}

Sylvia Johnston has a Master Degree in Sport Management, and has been the Sport Tourism Officer for city of Evex for about 5 years. Evex is a medium sized city with a population of 250,000 inhabitants in Canada. As a Sport Tourism officer, Sylvia is responsible for successfully attracting and hosting sport events and meetings, which are consistent with the goals of Evex's Tourism Strategy. Evex recently launched a sport event tourism strategy as a means to diversify their local industry. To that purpose, the city needs to select different types of events it wants to attract in order to generate the best possible tourism outcomes (e.g., Gibson, 2003; Higham, 1999). In addition to enhancing tourism, the city wants to create an image of a "Fun Fit City" for its residents, thereby stimulating opportunities for sport participation. Since "sport" is at the core of sport events, it is reasonable to believe that sport events stimulate sport participation. However, from the literature it appears that sport events may only benefit those who are already involved in sport rather than stimulating new participation (e.g., Taks et al., 2014; Misener et al., 2015; Weed et al. 2015). Nevertheless, besides enhancing tourism, city councilors believe that sport events can also stimulate sport participation among residents.

Based on available data from real cases of previously hosted events in other cities, Sylvia Johnston is tasked to write a report for the Evex City Council with recommendations of which type(s) of event(s) the city should select and bid for next year, based on their public policy agenda of enhancing tourism, and the potential for increasing sport participation of residents. In order to do so, Sylvia will have to: (1) create profiles of event attendees based on demographics, etc.; (2) find out about their motives for attending the events (i.e., are any of these motives related to tourism and/or sport participation); and, (3) investigate which type of tourism activities visitors engage in, and to what extent. Thus, the objective of this case is to make a recommendation 
(written and/or orally) to Evex City Council for going after a sport event, based on selecting and applying appropriate statistical concepts and techniques on a data set from survey responses of two real events.

\section{Background Information}

Sylvia Johnston contacted SMIC, a Sport Marketing Information Centre, which conducts studies around sport events in order to get some information about previously hosted events in other cities. Because of budget constraints, she was unable to have SMIC write a report and the necessary recommendations on the related topics. Instead, for a minimal price, she was able to get a hold of some research materials, including a questionnaire, a code book and a data set, from two different types of small to medium sized events (SME). She is looking to determine what type of event would be most strategic for the City of Evex, and this data should help guide the decision making process. As part of gathering information about event hosting, she will need to conduct a review of relevant literature and analyze the data provided by SMIC. A thorough analysis of the data, alongside a review of relevant literature, should enable Sylvia to provide recommendations to Evex City Council as to which type of event the city should select and bid for next year.

\section{Theoretical Considerations}

Sylvia still had access to the library at her former University and was able to perform a series of searches for relevant literature. She performed a series of searches, using keywords such as: sport eventourism, sport participation, legacy, and leveraging. From this initial search, it became clear that sport events have indeed become part of broader public policy agendas for cities in terms of urban development, place marketing, tourism, and economic development (e.g., Clark \& Misener, 2015). That is, cities are using events for what they consider beneficial outcomes for the host region. Most of the research on impacts, or what is often termed 'legacy' of 
events, has focused on mega sport events (MSE) such as the Olympic Games, the FIFA World Cup or the Commonwealth Games (e.g., Solberg \& Preuss, 2007). However, smaller sized cities are not in a position to host these types of MSE because they lack the necessary financial, physical and human resources (Agha \& Taks, 2015), yet there may be valuable outcomes from hosting smaller events (e.g., e.g., Higham, 1999; Taks, Chalip \& Green, 2015). In order to accrue positive impacts for the host community, event organizers need to understand what motivates people to attend events, and what additional activities they participate in while visiting the area (e.g.,Snelgrove , Taks, Chalip, \& Green, 2008).

Attracting non-locals to the area can create opportunities for flow-on tourism (i.e., tourism activities beyond the event but around the time of the event), thereby potentially stimulating other industries in the local economy (e.g., Gibson, 2003; Gibson, Kaplanidou, \& Kang, 2012; Taks, Chalip, Green, Kesenne, \& Martyn, 2009; Taks, Green, Chalip, Kesenne, \& Martyn, 2013). Research from non-mega sport events shows potential for personal growth and skill development of local residents (e.g., through volunteering, officiating, organizing), which may benefit sport participation opportunities in host communities (Taks, Green, Misener, \& Chalip, 2014; Misener, Taks, Chalip \& Green, 2015), however to date there is little support for the claim that events engender further sport participation (Weed et al., 2015). As a result of these claims, the idea that in order to accrue benefits to the local area, outcomes need to be strategically planned (i.e. leveraging; Chalip, 2014). Thus, if enhancing tourism and stimulating sport participation are desired outcomes, implementing strategies and tactics to leverage the event, are essential to enhance these outcomes. It may also be necessary to consider how events are strategically placed within the context of city developments, taking into account the capacity flow throughout the 
calendar year, something which has been referred to as an event portfolio (e.g. Ziakas \& Costa, 2011).

\section{Description of the Two Events}

The two events in the data set pertain to an international figure skating event (SKATE) and a provincial gymnastics event (GYM). They were both hosted in medium sized cities in Ontario (Canada) (see Figure 1). The 2013 World Figure Skating Championships (SKATE) was hosted at the Budweiser Gardens in London (Ontario) from March 11-17. The event attracted 9,708 spectators, of which 6,525 (or 67\%) were from outside of London (i.e. visitors; CSTA, 2013). The second event, the 2012-2013 Men's and Women's Ontario Artistic Championships (GYM) was hosted at the Field House of the University of Windsor (Windsor, Ontario) from April 4-7. The event attracted approximately 800 athletes and 1000 spectators (Wasser \& Taks, 2014). The spectator profiles suggest that only a small portion of the GYM attendees were locals (i.e., only relatives and friends of local qualifying gymnasts). Note that the samples for the two events include both local (i.e., "residents") and non-local (i.e., "visitors") event attendees. This distinction is relevant, as only visitors (i.e., non-local event attendees) should be included when analyzing tourism behaviour.

\section{Questionnaire}

A similar questionnaire was employed in both cases (see appendix A). Flyers with a request to fill out an online version of the questionnaires were handed out to spectators as they exited the event. In return for completing the questionnaire, participants were entered into a draw to win a $\$ 100$ cash prize. The questionnaires captured information on the respondents' identity and motives for attending the event, enquired about their tourism activities, and collected some sociodemographic characteristics. Clearly, some of the motives in the questionnaires aligned with the 
strategic objectives of the city for hosting events, such as motives to learn about the destination (i.e, tourism) and sport participation (e.g., learn about pathways to get involved in sport).

\section{Measurements}

A detailed overview of all the measurements was provided to Sylvia. The questionnaires and measurements were similar for both events and are described in the codebook (see Appendix B). The 10 questions from the questionnaire (see Questionnaire and column 2 in the Codebook), measure a total of 53 variables (see column 1 in the Codebook).

Identification. In order to understand the nature of attendees at the sporting events, Sylvia needs to explore how individuals identify with the event. From her sport marketing class, Sylvia remembered that identification with a sport reflects how people describe themselves (selfidentity) or how other people describe other individuals (social identity) as being part of a sport subculture (Shamir, 1992; Green, 2001). Identification in the context of events is important, since a high level of identification with the sport stimulates the desire and decision to attend events, while attending events, in turn, may also reinforce spectators' own personal identity (Pons et al., 2006). The questionnaires contained two measures for identification; one related to identification with the specific sport (see question 7, 3 items; e.g., I do not have/I have strong feelings about [THE SPORT]), and the second related to identification with attending events in general (see question 9, 3 items; e.g., I do not/I do have strong feelings about sports events in general). Both measures reflected self-identity and consisted of three items each based on Shamir's (1992) 6point Likert scale of self and social identity (from $1=$ no identification to $6=$ strong identification). Sylvia also remembered from her statistics class, that measurements for overarching constructs could be calculated based on the average score of the items that measure that particular dimension, on the condition the items show sufficient internal consistency. Thus, 
she was aware that first, the internal consistency of the items for each construct (i.e., identification with the specific sport; identification with sport events in general) needs to be tested, before the average score of the three items in each construct should be calculated.

Motives for attending the event. Similar to identity, Sylvia recalled that motives were important for event attendees. Motives drive behaviour, therefore, finding out what motivates people to attend events provides information to sport event organizers and policy makers how to attract spectators to the events. Six motivational dimensions were measured in total. Five dimensions were based on Beard and Ragheb's (1983) leisure motivation scale and one dimension, the entertainment experience (i.e., performance), was based on Kim and Chalip's (2004) fan motivation scale. Four of the leisure dimensions were similar to the ones used by Snelgrove et al. (2008), including social, escape, learning about the destination, and learning about athletics. As per the theory of Planned Behaviour (Ajzen, 1985) people go through various stages of contemplation and intention prior to participation. One of those stages measured here was in terms of learning about the sport and learning about pathways to get involved in the sport, which ties to the desired strategic outcome of eventually increasing sport participation. Note that the items related to learning about pathways to get involved in the sport were newly created and not previously used in other studies. All constructs were measured with three items each, and were based on a 6-point Likert scale ranging from strongly disagree (1) to strongly agree (6). As was the case for identity, first internal consistency of the items in each constructs needs to be tested before an overall score for each construct can be calculated by taking the average of the three items in each dimension.

Tourism activities. The questionnaires and data set also provided information on the tourism activities which attendees undertook during the events (i.e., flow-on tourism; Higham, 1999; Taks 
et al., 2011). Sylvia was well aware that if the city's public policy agenda was to enhance tourism for economic development purposes, thus she needed to provide evidence if, and to what extent these events stimulate tourism behavior of visitors (i.e., non-local event attendees). Obviously, the underlying assumption is that stimulating the tourism industry positively contributes to economic development as these visitors have direct expenditures that add to the local economy. The questionnaires enquire about the number of times visitors expected to participate in a series of activities while attending the sport event, thus it is important to exclude local residents from this portion of the data collected. Dining, shopping, recreation and sporting activities, and visiting parks and gardens are also defined as mundane tourism activities; while nightlife, museums and galleries, music and performing arts, and gaming are considered classic tourism activities (Taks et al., 2011).

Socio-demographic variables. Understanding the characteristics of visitors is important to determine the types of events, activities, and marketing strategies necessary to attract visitors to the event and the city. The socio-demographic variables in the questionnaires consisted of: place of residence (which distinguishes between local "residents" and non-local "visitors"), sex, age, educational status and income level. This information will assist in understanding visitors' profiles of the spectators at each type of event.

\section{Discussion Questions}

By selecting and applying appropriate statistical concepts and techniques, a thorough analysis of the data will assist Sylvia Johnston to determine which types of events the city should pursue to best serve their goals of enhancing tourism from visitors for economic development purposes, and/or sport participation opportunities for residents. In order to prepare a solid recommendation in the report to Evex City Council the following analyses will be helpful: 
1. Are the profiles of visitors different at the two events? (i.e., describe their socio-demographic characteristics).

2. Are the identity and motives of the spectators different according to the type of event? (i.e., calculate and compare the theoretical constructs for motivation and identity)

3. Which identity and motive constructs are related to the focal point of the case, namely enhancing tourism and stimulating sport participation? Is learning about the destination (i.e., indicator of interest in tourism) an important motive for attending these events? Is learning about pathways to participate in sport (i.e., indicator of interest in sport participation) an important motive to attend these events?

4. Are visitors at the two types of events engaging in different tourism activities?

5. Based on the interpretation of the results and review of relevant literature, and the conclusions thereof, which event should Sylvia Johnston recommend to: (a) enhance tourism, and (b) stimulate sport participation.

\section{References}

Agha, N. \& Taks, M. (2015). A theoretical comparison of the economic impact of large and small events. International Journal of Sport Finance, 10, 199-216.

Beard, J.G., \& Ragheb, M.G. (1983). Measuring leisure motivation. Journal of Leisure Research, $15,219-228$.

Chalip, L. (2004). Beyond impact: A general model for sport event leverage. In B. Ritchie and D. Adair. (Ed.), Sport tourism: Interrelationships, impacts and issues (pp. 226-252). Clevedon, UK.: Channel View Publications.

Chalip, L. (2014). From legacy to leverage. In J. Grix (Ed.), Leveraging legacies from sports mega-events: Concepts and cases (pp. 1-12). New York: Palgrave MacMillan. 
Clark, R., \& Misener, L. (2015). Understanding urban development through a sport events portfolio: A case study of London, Ontario. Journal of Sport Management, 29(1), 11-26.

CSTA (2013). 2013 ISU World Figure Skating Championships London, Ontario: Economic Impact Assessment. Ottawa, ON: Canadian Sport Tourism Alliance.

Gibson, H. J. (2003). Sport tourism: An introduction to the special issue. Journal of Sport Management, 17(3), 205-213.

Gibson, H. J., Kaplanidou, K., \& Kang, S. J. (2012). Small-scale event sport tourism: A case study in sustainable tourism. Sport Management Review, 15, 160-170.

Green, B.C. (2001). Leveraging subculture and identity to promote sport events. Sport Management Review, 4, 1-20.

Higham, J. (1999). Commentary - sport as an avenue of tourism development: An analysis of the positive and negative impacts of sport tourism. Current Issues in Tourism, 2(1), 82-90.

Misener, L., Taks, M., Chalip, L., \& Green, B.C. (2015). The elusive 'trickle down effect' of sport events: Assumptions and missed opportunities. Managing Sport and Leisure, 20(2), 135156.

Pons, F., Mourali, M., \& Nyeck, S. (2006). Consumer orientation toward sporting events: scale development and validation. Journal of Service Research, 8, 276-287.

Shamir, B. (1992). Some correlates of leisure identity salience: hree exploratory studies. Journal of Leisure Research, 24, 301-323.

Solberg, H., \& Preuss, H. (2007). Major sport events and long-term tourism impacts. Journal of Sport Management, 21(2), 213-234.

Snelgrove, R., Taks. M., Chalip. L, \& Green, B.C. (2008). How visitors and locals at a sport event differ in motives and identity. Journal of Sport \& Tourism, 13, 165-180. 
Taks, M., Chalip, L., \& Green, B.C. (2015). Impacts and strategic outcomes from non-mega sport events for local communities (introduction to the special issue). European Sport Management Quarterly, 15(1), 1-6.

Taks, M., Chalip, L., Green, B.C., Kesenne, S., \& Martyn, S. (2009). Factors affecting repeat visitation and flow-on tourism as sources of event strategy sustainability. Journal of Sport and Tourism, 14 (2/3), 121-142.

Taks, M., Green, B.C., Chalip, L., Kesenne, S., \& Martyn, S. (2013) Visitor composition and event-related spending. The International Journal of Event and Festival Management, 7, 132-147.

Taks, M., Green, B.C., Misener, L., \& Chalip, L. (2014). Evaluating sport development outcomes: The case of a medium sized international sport event. European Sport Management Quarterly, 14, 213-237.

Taks, M., Kesenne, S., Chalip, L., Green, B.C., \& Martyn, S. (2011). Economic impact study versus cost-benefit analysis: An empirical example of a medium sized international sporting event. International Journal of Sport Finances, 6(3), 187-203.

Wasser, K. \& Taks, M. (2014). In search of leveraging opportunities for a medium-sized sport event in a medium-sized city. In North American Society for Sport Management Conference Abstracts (pp. 555-556). Pittsburgh, PA: Duquesne University.

Weed, M., Coren, E., Fiore, J., Wellard, I., Chatziefstathiou, D., Mansfield, L., \& Dowse, S. (2015). The Olympic Games and raising sport participation: A systematic review of evidence and an interrogation of policy for a demonstration effect. European Sport Management Quarterly, 15(2), 195-226.

Ziakas, V., \& Costa, C. A. (2011). Event portfolio and multi-purpose development: Establishing the conceptual grounds. Sport Management Review, 14, 409-423. 

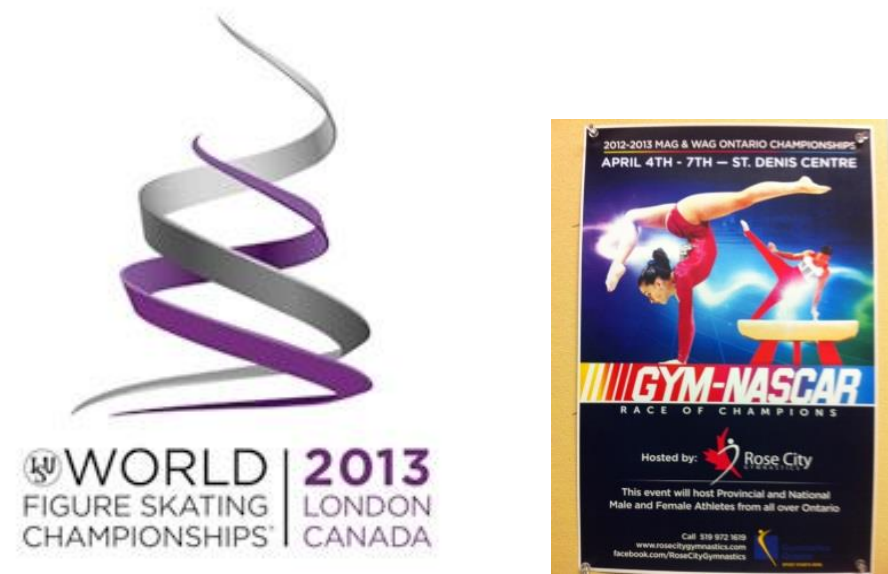

Figure 1: Two Small-Medium Sized Sport Events (SME) 


\section{Appendix A: QUESTIONNAIRE}

1. Is the EVENT the main reason for being in the CITY today?

$\square$ Yes $\square$ No

2. Have you previously attended this EVENT live (in person)?

$\square$ Yes $\square$ No

3. How did you hear about the EVENT? (check all that apply)
Newspaper
E-mail
Friends/Family
$\square$ Flyer
Figure Skating Club
Magazine
TV
$\square$ Internet
Poster/Banner $\quad \square$ Radio

Other, (specify):

4. Do you live outside the City? $\square$ Yes $\square$ No

Home Country:

Home City:

5. How many days it total, will you be attending the EVENT?
1 days
$\square 2$ days
$\square 3$ days $\square 4$ days
$\square 5$ days
6 days $\square 7$ days

6. Please check the number of times you expect to do the activities listed in bold while visiting the CITY $(0=$ not at all; $1=1$ time; $2=2$ times; $3=3$ times, $\geq 4=4$ or more times $)$

\begin{tabular}{|l|rllll|}
\hline Tourism activity & Number of times participating in activities \\
\hline Dining out & $\square \mathbf{0}$ & $\square \mathbf{1}$ & $\square \mathbf{2}$ & $\square \mathbf{3}$ & $\square \geq \mathbf{4}$ \\
\hline Nightlife & $\square \mathbf{0}$ & $\square \mathbf{1}$ & $\square \mathbf{2}$ & $\square \mathbf{3}$ & $\square \geq \mathbf{4}$ \\
\hline Shopping & $\square \mathbf{0}$ & $\square \mathbf{1}$ & $\square \mathbf{2}$ & $\square \mathbf{3}$ & $\square \geq \mathbf{4}$ \\
\hline Museums and Galleries & $\square \mathbf{0}$ & $\square \mathbf{1}$ & $\square \mathbf{2}$ & $\square \mathbf{3}$ & $\square \geq \mathbf{4}$ \\
\hline Music \& Performing Arts & $\square \mathbf{0}$ & $\square \mathbf{1}$ & $\square \mathbf{2}$ & $\square \mathbf{3}$ & $\square \geq \mathbf{4}$ \\
\hline Parks and Gardens & $\square \mathbf{0}$ & $\square \mathbf{1}$ & $\square \mathbf{2}$ & $\square \mathbf{3}$ & $\square \geq \mathbf{4}$ \\
\hline Recreational/Sporting Activities & $\square \mathbf{0}$ & $\square \mathbf{1}$ & $\square \mathbf{2}$ & $\square \mathbf{3}$ & $\square \geq \mathbf{4}$ \\
\hline Gaming & $\square \mathbf{0}$ & $\square \mathbf{1}$ & $\square \mathbf{2}$ & $\square \mathbf{3}$ & $\square \geq \mathbf{4}$ \\
\hline
\end{tabular}


7. For the following items, please circle the number that most closely represents how you feel about each of the following statements related to the specific SPORT you are attending:

$\begin{array}{lllllllll}\begin{array}{l}\text { Being a fan of [SPORT] } \\ \text { does not describe me }\end{array} & 1 & 2 & 3 & 4 & 5 & 6 & \begin{array}{l}\text { being a fan of [SPORT] } \\ \text { describes me }\end{array}\end{array}$

$\begin{array}{lllllllll}\begin{array}{l}\text { Being a fan of [SPORT] } \\ \text { does not affirm my values }\end{array} & 1 & 2 & 3 & 4 & 5 & \begin{array}{c}\text { 6 Being a fan of [SPORT] } \\ \text { affirms my values }\end{array}\end{array}$

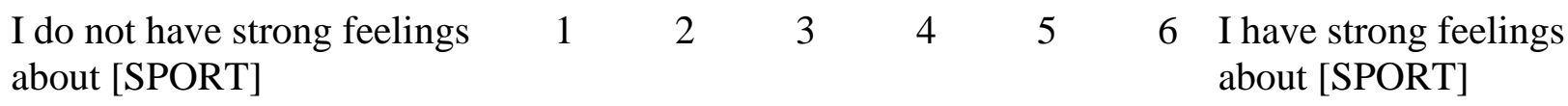

8. Spectators have many reasons for attending the [EVENT]. Please rate how important each reason is to you, using the following scale:

\begin{tabular}{|c|c|c|c|c|c|c|}
\hline $\begin{array}{l}\text { One of the reasons for attending the Figure } \\
\text { Skating Championships is: }\end{array}$ & $\begin{array}{l}\text { Strongly } \\
\text { Disagree }\end{array}$ & $\begin{array}{c}\text { Dis- } \\
\text { agree }\end{array}$ & $\begin{array}{l}\text { Slightly } \\
\text { Disagree }\end{array}$ & $\begin{array}{l}\text { Slightly } \\
\text { Agree }\end{array}$ & Agree & $\begin{array}{l}\text { Strongly } \\
\text { Agree }\end{array}$ \\
\hline $\begin{array}{l}\text { to satisfy my curiosity about Figure Skating } \\
\text { [LEARNS 1] }\end{array}$ & 1 & 2 & 3 & 4 & 5 & 6 \\
\hline to build friendships with others [SOC_1] & 1 & 2 & 3 & 4 & 5 & 6 \\
\hline to get away from my everyday life [ESC_1] & 1 & 2 & 3 & 4 & 5 & 6 \\
\hline to watch high level Figure Skating [PERF_1] & 1 & 2 & 3 & 4 & 5 & 6 \\
\hline $\begin{array}{l}\text { to expand my knowledge about the CITY, } \\
\text { the province of Ontario, and/or Canada } \\
\text { [LEARND_1] }\end{array}$ & 1 & 2 & 3 & 4 & 5 & 6 \\
\hline $\begin{array}{l}\text { to discover new things about Figure Skating } \\
\text { [LEARNS_2] }\end{array}$ & 1 & 2 & 3 & 4 & 5 & 6 \\
\hline $\begin{array}{l}\text { To explore [SPORT] opportunities in the } \\
\text { area [PATH_1] }\end{array}$ & 1 & 2 & 3 & 4 & 5 & 6 \\
\hline $\begin{array}{l}\text { to discover new things about The CITY, the } \\
\text { province of Ontario, and/or Canada } \\
\text { [LEARND_2] }\end{array}$ & 1 & 2 & 3 & 4 & 5 & 6 \\
\hline $\begin{array}{l}\text { to see future stars of Figure Skating } \\
\text { [PERF_2] }\end{array}$ & 1 & 2 & 3 & 4 & 5 & 6 \\
\hline to interact with others [SOC_2] & 1 & 2 & 3 & 4 & 5 & 6 \\
\hline to relax physically [ESC_1] & 1 & 2 & 3 & 4 & 5 & 6 \\
\hline
\end{tabular}




\begin{tabular}{|c|c|c|c|c|c|c|}
\hline $\begin{array}{l}\text { to expand my knowledge about Figure } \\
\text { Skating [LEARND_3] }\end{array}$ & 1 & 2 & 3 & 4 & 5 & 6 \\
\hline to meet new and different people [SOC_3] & 1 & 2 & 3 & 4 & 5 & 6 \\
\hline $\begin{array}{l}\text { to learn more about getting involved in the } \\
\text { SPORT [PATH_2] }\end{array}$ & 1 & 2 & 3 & 4 & 5 & 6 \\
\hline $\begin{array}{l}\text { to be a part of a major Figure Skating event } \\
\text { [PERF_3] }\end{array}$ & 1 & 2 & 3 & 4 & 5 & 6 \\
\hline $\begin{array}{l}\text { to satisfy my curiosity about The CITY- } \\
\text { Middlesex County, the province of Ontario, } \\
\text { and/or Canada [LEARND_3] }\end{array}$ & 1 & 2 & 3 & 4 & 5 & 6 \\
\hline to relax mentally [ESC_3] & 1 & 2 & 3 & 4 & 5 & 6 \\
\hline $\begin{array}{l}\text { to discover ways to get involved in SPORT } \\
\text { [PATH_3] }\end{array}$ & 1 & 2 & 3 & 4 & 5 & 6 \\
\hline
\end{tabular}

9. For the following items, please circle the number that most closely represents how you feel about attending SPORT EVENTS IN GENERAL:

\begin{tabular}{lllllllll}
$\begin{array}{l}\text { Being an avid supporter } \\
\text { of local sporting events } \\
\text { does not describe me }\end{array}$ & 1 & 2 & 3 & 4 & 5 & $6 \begin{array}{r}\text { Being an avid supporter } \\
\text { of local sporting events } \\
\text { describes me }\end{array}$ \\
\hline
\end{tabular}

$\begin{array}{llllllll}\text { I rarely travel to attend } & 1 & 2 & 3 & 4 & 5 & 6 & \text { I frequently travel to }\end{array}$ sporting events attend sporting events

$\begin{array}{llllllll}\text { I do not have strong feelings } & 1 & 2 & 3 & 4 & 5 & 6 & \text { I have strong feelings }\end{array}$ about sport events in general about sport events in general

\section{Some general information about yourself (please check the appropriate box or fill out)}

10. Your Gender? $\square$ Female $\quad \square$ Male

11. What is your age? (check the category that applies): $\square$ 18-34 $\square 35-54 \quad \square 55$ or older

12. Your highest level of education?

Elementary School, some High School, High School Graduate

$\square$ Some university or higher education

$\square$ University or higher education graduate

$\square$ Graduate school

13. What is your Annual Household Income (in CND \$)?

$\square$ Under $\$ 50,000 \square \$ 50,000$ - \$99,999 $\square \$ 100,000$ or more $\square$ Prefer not to answer 
Appendix B: CODEBOOK

\begin{tabular}{|c|c|c|c|c|c|c|}
\hline $\begin{array}{l}\# \\
\text { Var. }\end{array}$ & $\begin{array}{l}\text { Ques } \\
\text { tion }\end{array}$ & Label & Description & Coding & Min. & Max \\
\hline 1 & & ID & Identification & 1 to 322 & 1 & 172 \\
\hline 2 & & Sport & Type of sport & $\begin{array}{l}1=\text { SKATE } \\
2=\text { GYM }\end{array}$ & 1 & 2 \\
\hline 3 & Q.1 & Primary_att & $\begin{array}{l}\text { Is the EVENT the main reason } \\
\text { for being in the city today? }\end{array}$ & $\begin{array}{l}0=\text { no } \\
1=\text { yes }\end{array}$ & 0 & 1 \\
\hline 4 & Q.2 & Live_att & $\begin{array}{l}\text { Have you previously attended } \\
\text { this EVENT live }\end{array}$ & $\begin{array}{l}0=\text { no } \\
1=\text { yes }\end{array}$ & 0 & 1 \\
\hline & Q.3 & & $\begin{array}{l}\text { How did you hear about this } \\
\text { event: }\end{array}$ & $\begin{array}{l}0=\text { no } \\
1=\text { yes }\end{array}$ & 0 & 1 \\
\hline 5 & 3.1 & MC_Newsp & Newspaper & \multirow{11}{*}{\multicolumn{3}{|c|}{ See Q. 3}} \\
\hline 6 & 3.2 & MC_Email & E-mail & & & \\
\hline 7 & 3.3 & MC_FF & Friends/Family & & & \\
\hline 8 & 3.4 & MC_Flyer & Flyer & & & \\
\hline 9 & 3.5 & MC_Club & Sport Club & & & \\
\hline 10 & 3.6 & MC_Mag & Magazine & & & \\
\hline 11 & 3.7 & MC_TV & $\mathrm{TV}$ & & & \\
\hline 12 & 3.8 & MC_Web & Internet & & & \\
\hline 13 & 3.9 & MC_Poster & Poster/Banner & & & \\
\hline 14 & 3.10 & MC_Radio & Radio & & & \\
\hline 15 & 3.11 & MC_Other & Other (specify) & & & \\
\hline 16 & Q.4 & Residence & Do you live outside the city? & $\begin{array}{l}0=\text { no }(=\text { local }) \\
1=\text { yes }(=\text { non-local })\end{array}$ & 0 & 1 \\
\hline \multirow[t]{2}{*}{17} & Q.5 & Stay_length & $\begin{array}{l}\text { How many days it total, will } \\
\text { you be attending the EVENT? }\end{array}$ & $\begin{array}{l}1=1 \text { day } \\
2=2 \text { days } \\
7 \\
7=7 \text { days }\end{array}$ & 1 & 7 \\
\hline & Q.6 & & $\begin{array}{l}\text { Number of times you expect to } \\
\text { participate in the following } \\
\text { tourism activities while } \\
\text { visiting the CITY }\end{array}$ & $\begin{array}{l}0=\text { no participation } \\
1=1 \text { time } \\
2=2 \text { times } \\
3=3 \text { times } \\
4=\geq 4 \text { times }\end{array}$ & 0 & 4 \\
\hline 18 & 6.1 & T_dining_n & Dining & \multirow{8}{*}{\multicolumn{3}{|c|}{ See Q. 6}} \\
\hline 19 & 6.2 & T_night_n & Nightlife & & & \\
\hline 20 & 6.3 & T_shop_n & Shopping & & & \\
\hline 21 & 6.4 & T_Muse_n & Museums and Galleries & & & \\
\hline 22 & 6.5 & T_PA_n & Music and Performing arts & & & \\
\hline 23 & 6.6 & T_parks_n & Parks and Gardens & & & \\
\hline 24 & 6.7 & T_rec_n & $\begin{array}{r}\text { Recreational/Sporting } \\
\text { Activities }\end{array}$ & & & \\
\hline 25 & 6.8 & T_Game_n & Gaming & & & \\
\hline & Q.7 & & $\begin{array}{l}\text { Self-identification with the } \\
\text { [SPORT]: }\end{array}$ & $\begin{array}{l}1=\text { not at all } \\
\ldots \\
6=\text { very much }\end{array}$ & 1 & 6 \\
\hline
\end{tabular}




\begin{tabular}{|c|c|c|c|c|c|c|}
\hline 26 & 7.1 & ID_SPORT1 & $\begin{array}{r}\text { Being a fan of [SPORT] } \\
\text { Describes me }\end{array}$ & \multirow{3}{*}{\multicolumn{3}{|c|}{ See Q.7 }} \\
\hline 27 & 7.2 & ID_SPORT2 & $\begin{array}{r}\text { Being a fan of [SPORT] } \\
\text { Affirms my values }\end{array}$ & & & \\
\hline \multirow[t]{2}{*}{28} & 7.3 & ID_SPORT3 & $\begin{array}{r}\text { I have strong feelings about } \\
\text { [SPORT] }\end{array}$ & & & \\
\hline & Q.8 & & $\begin{array}{l}\text { Reasons for attending the } \\
\text { EVENT }\end{array}$ & $\begin{array}{l}1=\text { strongly } \\
\text { disagree } \\
\ldots \\
6=\text { strongly agree }\end{array}$ & 1 & 6 \\
\hline 29 & 8.1 & LEARNS_1 & $\begin{array}{l}\text { to satisfy my curiosity about } \\
\text { Figure Skating }\end{array}$ & \multirow{18}{*}{ 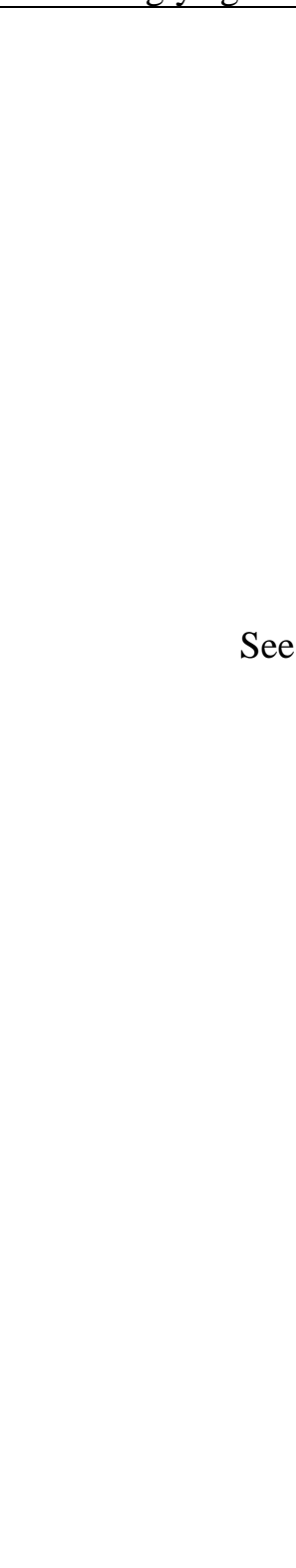 } & & \\
\hline 30 & 8.2 & SOC_1 & to build friendships with others & & & \\
\hline 31 & 8.3 & ESC_1 & $\begin{array}{l}\text { to get away from my everyday } \\
\text { life }\end{array}$ & & & \\
\hline 32 & 8.4 & PERF_1 & $\begin{array}{l}\text { to watch high level Figure } \\
\text { Skating }\end{array}$ & & & \\
\hline 33 & 8.5 & LEARND_1 & $\begin{array}{l}\text { to expand my knowledge } \\
\text { about the CITY, the province } \\
\text { of Ontario, and/or Canada }\end{array}$ & & & \\
\hline 34 & 8.6 & LEARNS_2 & $\begin{array}{l}\text { to discover new things about } \\
\text { Figure Skating }\end{array}$ & & & \\
\hline 35 & 8.7 & LEARND_2 & $\begin{array}{l}\text { to discover new things about } \\
\text { The CITY, the province of } \\
\text { Ontario, and/or Canada }\end{array}$ & & & \\
\hline 36 & 8.8 & PATH_1 & $\begin{array}{l}\text { to explore [SPORT] } \\
\text { opportunities in the area }\end{array}$ & & & \\
\hline 37 & 8.9 & PERF_2 & $\begin{array}{l}\text { to see future stars of Figure } \\
\text { Skating }\end{array}$ & & & \\
\hline 38 & 8.10 & SOC_2 & to interact with others & & & \\
\hline 39 & 8.11 & ESC_2 & to relax physically & & & \\
\hline 40 & 8.12 & LEARNS_3 & $\begin{array}{l}\text { to expand my knowledge } \\
\text { about Figure Skating }\end{array}$ & & & \\
\hline 41 & 8.13 & SOC_3 & $\begin{array}{l}\text { to meet new and different } \\
\text { people }\end{array}$ & & & \\
\hline 42 & 8.14 & PATH_2 & $\begin{array}{l}\text { to learn more about getting } \\
\text { involved in the SPORT }\end{array}$ & & & \\
\hline 43 & 8.15 & PERF_3 & $\begin{array}{l}\text { to be a part of a major Figure } \\
\text { Skating event }\end{array}$ & & & \\
\hline 44 & 8.16 & LEARND_3 & $\begin{array}{l}\text { to satisfy my curiosity about } \\
\text { the CITY/region, the province } \\
\text { of Ontario, and/or Canada }\end{array}$ & & & \\
\hline 45 & 8.17 & ESC_3 & to relax mentally & & & \\
\hline 46 & & PATH_3 & $\begin{array}{l}\text { to discover ways to get } \\
\text { involved in SPORT }\end{array}$ & & & \\
\hline
\end{tabular}

\begin{tabular}{|l|l|l|l|l|l|c|}
\hline & Q.9 & & $\begin{array}{l}\text { Self-identification with the } \\
\text { sport events in general }\end{array}$ & $\begin{array}{l}1=\text { not at all } \\
\ldots \\
6=\text { very much }\end{array}$ & 1 & 6 \\
\hline
\end{tabular}




\begin{tabular}{|c|c|c|c|c|c|c|}
\hline 47 & 9.1 & $\begin{array}{l}\text { ID_EVENTS_ } \\
1\end{array}$ & $\begin{array}{r}\text { Being an avid supporter of } \\
\text { local sport events } \\
\text { Describes me }\end{array}$ & \multirow{3}{*}{\multicolumn{3}{|c|}{ See Q.9 }} \\
\hline 48 & 9.2 & $\begin{array}{l}\text { ID_EVENTS_ } \\
2\end{array}$ & $\begin{array}{r}\text { I frequently travel to attend } \\
\text { sporting events }\end{array}$ & & & \\
\hline 49 & 9.3 & $\begin{array}{l}\text { ID_EVENTS_ } \\
3\end{array}$ & $\begin{array}{l}\text { I have strong feelings about } \\
\text { sport events in general }\end{array}$ & & & \\
\hline 50 & Q.10 & SEX & Female or Male & $\begin{array}{l}0=\text { Male } \\
1=\text { Female }\end{array}$ & 18 & $\max$ \\
\hline 51 & Q.11 & Age_n & Age category & $\begin{array}{l}1=18 \text { to } 34 \\
2=34 \text { to } 54 \\
3=\geq 55\end{array}$ & 1 & 3 \\
\hline 52 & Q.12 & EDUC_n & Educational level & $\begin{aligned} 1= & \text { Elementary } \\
& \text { School, some } \\
& \text { High School, } \\
& \text { High School } \\
& \text { Graduate } \\
2= & \text { Some university } \\
& \text { or higher } \\
& \text { education } \\
3= & \text { University or } \\
& \text { higher education } \\
& \text { graduate } \\
4= & \text { Graduate school }\end{aligned}$ & 1 & 4 \\
\hline 53 & Q.13 & INC_n & Income category & $\begin{aligned} 1= & <\$ 50,000 \\
2= & \$ 50,000-\$ \\
& 99,999 \\
3= & \$ 100,000 \text { or } \\
& \text { more } \\
4= & \text { Prefer not to } \\
& \text { answer }\end{aligned}$ & 1 & 3 \\
\hline
\end{tabular}

